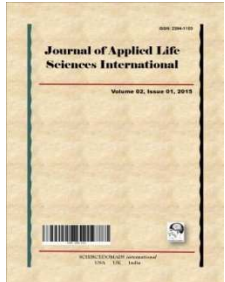

\title{
Analgesic, Non-ulcerogenic and Antioxidant Activities of the Aqueous Stem Bark Extract of Morinda lucida (Rubiaceae) in Mice
}

\author{
Mezui Christophe ${ }^{1^{*}}$, Amang Andre Perfusion ${ }^{2}$, Bougnom Blaise Pascal ${ }^{3}$, \\ Malepa Meda Ginette ${ }^{1}$, Tchinda Fokoua Serges ${ }^{1}$, Tchapmeni Fando Liliane ${ }^{1}$ \\ and Tan Paul Vernyuy ${ }^{4}$
}

${ }^{1}$ Department of Biological Sciences, Higher Teachers' Training College (ENS), University of Yaounde I, P.O.Box 047, Yaounde, Cameroon.

${ }^{2}$ Department of Biological Sciences, Faculty of Science, University of Maroua, P.O.Box 46, Maroua, Cameroon.

${ }^{3}$ Department of Microbiology, Faculty of Sciences, University of Yaounde I, P.O.Box 812, Yaounde, Cameroon.

${ }^{4}$ Department of Animal Biology and Physiology, Faculty of Sciences, University of Yaounde I, P.O.Box 812, Yaounde, Cameroon.

Authors' contributions

This work was carried out in collaboration between all authors. Authors MC and BBP designed the study and wrote the protocol. Authors MC, MMG and TFS managed the analgesic tests. Authors MC, $A A P$ and MMG managed the gastric ulcer tests. Authors BBP and TFL managed the antioxidant tests. Authors BBP and TFL did the phytochemical analysis. Authors MC and MMG did the literature search and statistical analysis. Authors MC and AAP wrote the first draft. Author TPV supervised the study. All authors read and approved the final manuscript.

Article Information

DOI: $10.9734 / J A L S I / 2017 / 33003$

Editor(s):

(1) Shahira M. Ezzat, Department of Pharmacognosy, Faculty of Pharmacy, Cairo University, Egypt. Reviewers:

(1) Papiya Bigoniya, Radharaman College of Pharmacy, Bhopal, India. (2) Walter Antonio Roman Junior, University of Chapeco (Unochapecó), Brazil. Complete Peer review History: http://www.sciencedomain.org/review-history/19094

Original Research Article

Received 27 $7^{\text {th }}$ March 2017 Accepted $10^{\text {th }}$ May 2017 Published $17^{\text {th }}$ May 2017

\section{ABSTRACT}

Aims: The objective of this study was to evaluate the analgesic; non ulcerogenic and antioxidant effects of the aqueous stem bark extract of Morinda lucida in mice.

Place and Duration of Study: Department of Biological Sciences, Higher Teachers' Training College; Department of Animal Biology and Physiology and Department of Microbiology, Faculty of 
Science, University of Yaoundé I. Between August 2015 and November 2016.

Materials and Methods: The phytochemical sifting was realized in other to find the chemical composition of the aqueous stem bark extract of Morinda lucida (ASBEML). The antioxydant activity was evaluated by the measurement the capacity of ASBEML to trap radical DPPH, to reduce $\mathrm{Fe}^{3+}$, and measures it total polyphenols. The effects of ASBEML were tested on models of acute pain induced by acetic acid and formalin in mouse fasted since 12 hours. The ulcerogenic effect of this plant was evaluated by administration of different doses of the aqueous extract to mouse fasted since 48 hours.

Results: The phytochemical tests revealed the presence of phenolics, flavonoïds, catechic tannins, alkaloids, saponins and triterpenes. The DPPH, FRAP and Folin-Ciocalteu tests showed that the aqueous stem bark extract of Morinda lucida has a significant antioxydant activity. The oral administration of ASBEML significantly and dose dependently reduced the number of abdominal constrictions induced by injection of acetic acid. A maximum inhibition of $80.20 \%$ was obtained at the dose of $400 \mathrm{mg} / \mathrm{kg}$. Also, this extract $(400 \mathrm{mg} / \mathrm{kg})$ significantly and dose dependently inhibited both phases of pain induced by formalin injection; the first phase was reduced up to $53.7 \%$ while the second phase was reduced up to $75.88 \%$. The oral administration of ASBEML doesn't caused gastric ulcer. On the contrary, it significantly and dose dependently stimulated the mucus secretion. Conclusion: In sum, the ASBEML possesses antioxidant, analgesic (centrally and peripherally) and non-ulcerogenic properties.

Keywords: Morinda lucida; Rubiaceae; antioxidant; pain; ulcer; mucus.

\section{INTRODUCTION}

According to the International Association for the Study of Pain (IASP), pain is an unpleasant sensory or emotional experience, linked to a real or potential tissue injury that causes protective motor and vegetative reactions, leading to individual modification behavior [1]. If acute pain is a warning signal that allows the individual to escape from the source of pain (stimulus), chronic pain is a severe disabling illness very often associated with other conditions such as osteoarthritis, rheumatism, cancer and many others. The consequences of chronic pain are very numerous, both organically and psychologically, with a behavioral modification that can go as far as anxio-depression and an increased risk of suicide [2]. It is increasingly high in the world because of its multiple causes. According to Stucky et al. [3], over the third of the world's population suffers from chronic pain.

The monthly prevalence of pain of any kind is $72.40 \%$ in England [4]. According to Jain et al. [5], each person suffers from pain at least once in his life. Pain affects the entire world population and is therefore a major problem of public health. Considering the increasing prevalence, the difficulties in the management and the numerous consequences of the pain, this pathology requires special attention and an effective treatment to avoid possible complications.
However, most pharmaceuticals used in the treatment of pain have many side effects and some of them are relatively inaccessible to all segments of society. NSAIDs (such as indomethacin, ibuprofen) remain the most widely used therapeutic class in the world for the treatment of pain and inflammation, whether in the context of medical prescription or that of selfmedication, because of their anti-inflammatory, antipyretic or analgesic properties and even inhibitory platelet aggregation [6]. However, these NSAIDs are responsible for a significant mortality generated mainly by their severe digestive adverse effects [7]. It is therefore essential to find new medicines available, less expensive, more effective and without side effects as far as possible.

Traditional medicine intervenes at this level. It is the first resort for primary health care, as about $80 \%$ of the population in developing countries is oriented towards traditional medicine, where $85 \%$ of treatments involve the use of plant extracts [8]. Plants are therefore a potential source of active ingredients that can lead to the development of new drugs. Moreover, 25 to $30 \%$ of the pharmaceutical products are of natural origin [9].

For example, Morinda lucida is a tree belonging to the Rubiaceae family [10]. The genus Morinda comprises about 80 species. In Africa, there are 5 species (Morinda citrifolia, Morinda geminata, Morinda longiflora, Morinda morindoides and 
Morinda lucida). The relatively small floral and fruiting heads on long thin peduncles are distinctive characters of Morinda lucida [11]. Morinda lucida is a plant measuring on average 15 to 18 meters, some specimens up to 25 meters [12]. Morinda lucida is still called: sulfur tree. In Cameroon, Morinda lucida is called ikeng (Bassa), akeng (Beti), keug (Makia) and didondedov (Bamiléké). This tree is also known as konkroma (Twi) in Ghana, and nfia (Igbo in Nigeria) [13]. Previous phytochemical studies have revealed the presence of several classes of compounds in the aqueous extract of Morinda lucida bark such as: tannins, phenols, reducing substances, saponins, glycosides and flavonoids. Phytochemical screening revealed that fatty acids and alkaloids were absent [14]. The study of the acute and subacute toxicity of the aqueous extract of Morinda lucida stem bark has shown that this extract is weakly toxic [15].

Previous studies have shown that Morinda lucida has several pharmacological virtues. The leaf extract treats malaria, gastric ulcers and diabetes. The root bark extract is used in the treatment of diabetes and also has bactericidal activity. The methanol extract of trunk bark has anti-malarial, anti-cancer [16] and antioxidant effects [17]. While the work of Domekouo et al. showed that the aqueous extract of Morinda lucida bark has antidiabetic and antioxidant properties [14]. Morinda lucida is used in traditional medicine in the treatment of pain [18] and peptic ulcers [14]. The bark of Morinda lucida thus possesses analgesic effects without adverse effects on the gastric mucosa. This led us to evaluate the analgesic, non-ulcerogenic and antioxidant effects of ASBEML.

\section{MATERIALS AND METHODS}

\subsection{Collection and Identification of Plant Material}

The stem barks of Morinda lucida was harvested in August 2015 at Yaoundé (Center Cameroon region). Botanical identification was done in the National herbarium of Cameroon (Yaounde), by comparison with existing voucher specimens $\mathrm{N}^{\circ}$ 2528 SRFK.

\subsection{Preparation of Extract}

In the laboratory, the barks were cut into pieces, dried under laboratory temperature and ground to powder. $1000 \mathrm{~g}$ was introduced in 5 liters of distilled water and then boiled on a heating plate for 15 minutes. The resulting solution was filtered using a $n^{\circ} 3$ Whatmann filter paper. The filtrate was lyophilized and the resulting brownish solid was used for the pharmacological tests. The resulting material weighed $37.50 \mathrm{~g}$, giving a percentage yield of $3.75 \%$ with respect to the powder.

\subsection{Animals}

Adult male Swiss albino mice Mus musculus $(25.00 \pm 5.00 \mathrm{~g})$ obtained from the Animal house, Laboratory of Animal Physiology, Department of Biological Sciences, Higher Teachers' Training College, University of Yaoundé I (YaoundéCameroon) were used for this study. Prior authorization for the use of laboratory animals in this study was obtained from the Cameroon National Ethics Committee (Reg. No. FWAIRB00001954). The use, handling and care of animals were done in adherence to the European Convention (Strasbourg, 18.III.1986) for the protection of vertebrate animals used for experimental and other purposes (ETS-123), with particular attention to Part III, articles 7, 8 and 9.

\subsection{Chemicals}

Acetic acid, formalin, indomethacin and the aqueous extract were prepared prior to their use in the biological assays.

\subsection{Phytochemical Tests}

The aqueous stem bark extract of Morinda lucida was subjected to qualitative chemical test for the identification of different phytoconstituents like phenols, catechic tannins, galic tannins, flavonoïds, alkaloids, saponins, triterpenes and sterols [19].

\subsection{Measurement of In vitro Antioxidant Capacity of Morinda lucida Extract}

\subsubsection{Measurement of folin antioxidant capacity}

Folin-Ciocalteu reagent (Sigma Chemical Co., St. Louis, MO) was diluted 10 -fold and used for the measurement of the Folin antioxidant capacity of the extract [20], and absorbance was measured at $750 \mathrm{~nm}$ after $10 \mathrm{~min}$. of reaction, using catechin as the standard. 
2.6.2 Measurement of ferric reducing antioxidant power (FRAP)

The ferric reducing antioxidant ability of the extract was measured by spectrophotometry [21]. The FRAP reagent $(2 \mathrm{~mL})$ was mixed with $30 \mu \mathrm{L}$ of hydrolysed extract and the absorbance was read at $593 \mathrm{~nm}$ after 12 minutes of incubation using a Spectronic GENESYS 5 incubator (Milton Roy Co.) equipped with a thermostat, autocell heating, and cooling water bath (Fischer Scientific). The temperature was maintained at $37^{\circ} \mathrm{C}$ and catechin was used as standard.

\subsubsection{Measurement of DPPH scavenging activity}

DPPH (1,1-diphenyl-2-picrylhydrazyl) radical scavenging activity of the extract was measured as earlier described [22]. An aliquot of the extract in methanol $(10 \mathrm{mg} / \mathrm{mL})$ was added to methanolic solutions of DPPH ( $1 \mathrm{mM}, 0.25 \mathrm{~mL})$. The mixture was shaken and left to stand for 30 minutes at room temperature. The absorbance of the solution was measured spectrophotometrically at $517 \mathrm{~nm}$ and the \% DPPH scavenging activity was calculated against the control.

\subsection{Investigating Analgesic Properties}

\subsubsection{Animal allotment and treatment}

In each analgesic test, five groups of 6 animals were used. Group 1 served as negative control and received distilled water $(0.5 \mathrm{ml} / 30 \mathrm{~g} \mathrm{bw})$. Group 2 was used as positive control and was treated with indomethacin (50 mg/kg per os). The 3 last groups received the aqueous extract of Morinda lucida at the doses 100; 200 and $400 \mathrm{mg} / \mathrm{kg}$ per os.

\subsubsection{Acetic acid-induced writhing test}

This test was conducted as previously described by Koster [23]. One hour after administration of the treatment, acetic acid solution $(0.6 \mathrm{v} / \mathrm{v})$ was injected intraperitoneally $(10 \mathrm{ml} / \mathrm{kg})$ to each animal. The number of writhing induced by the acetic acid, consisting of abdominal constrictions and hind limbs stretching were counted for 20 minutes after a latency period of 5 minutes. The percentage of inhibition was calculated as follows:

$$
\text { Percentage of inhibition }=1-\frac{\mathrm{Nt}}{\mathrm{Nc}} X 100
$$

Where, $\mathrm{Nc}$ is the average number of stretching in the control group, $\mathrm{Nt}$ is the average number of stretching in the test group.

\subsubsection{Formalin- induced pain}

The method was conducted as previously described by Gaertner et al. [24]. In this procedure, $20 \mu \mathrm{L}$ of $2.5 \%$ formalin was injected in the plantar arch of the right hind paw of the rats 1 hour after administration of drugs. These rats were individually placed in transparent cage for observation. The time spent licking the injected paw, was an indicator of the pain sensation following formalin administration, and was recorded in different phases: from 0-5 min post injection (first phase) and 15-30min post injection (second phase). These phases represented neurogenic and inflammatory pain response, respectively. The percentage of analgesic activity was calculated as follows:

$$
\text { Percentage of inhibition }=1-\frac{\mathrm{Tt}}{\mathrm{Tc}} X 100
$$

With Tc is the mean time in control group for each phase and $\mathrm{Tt}$ is the mean time in the test group for each phase.

\subsection{Investigating Non-ulcerogenic Properties}

\subsubsection{Ulcerogenic test}

This test was assayed according to Grewal et al. [25]. Five hours after administration of drugs, mice were sacrificed under ether anaesthesia. The abdomen of each mouse was opened and stomach was located and removed after bindings at the levels of the cardia and the pylori. Each stomach was dilated by injection of $1 \mathrm{ml}$ of formalin at $2 \%$ and was open along the greatest curve to examine macroscopically lesions.

\subsubsection{Ulcer scores}

The ulcers produced in the glandular region of each stomach were measured and scored as described by Martin et al. [26].

\begin{tabular}{ll}
\hline Description & Scores \\
\hline No ulcers & 0,0 \\
$\begin{array}{l}\text { Dilation of the vessels and small } \\
\text { points of ulcers }\end{array}$ & 1,0 \\
$\begin{array}{l}\text { Ulcers lower or equal to } 4 \mathrm{~mm} \\
\text { length }\end{array}$ & 2,5 \\
$\begin{array}{l}\text { Ulcers equal or higher to } 5 \mathrm{~mm} \\
\text { length }\end{array}$ & 5 \\
\hline
\end{tabular}




\subsubsection{Ulcer index (UI)}

The ulcer index (UI) is the average score of ulcers of each treatment \pm the standard error on the mean (ESM) and calculated as follows:

$$
\mathrm{IU}=\sum_{1}^{n} \text { Scores } \pm E S M
$$

\subsubsection{Percentage of ulceration}

The percentage of ulceration was calculated respectively to the ulcerated surface (US) $\left(\mathrm{mm}^{2}\right)$ by the following formula:

$$
\text { U.S. }=\left(\frac{\text { Total ulcerated surface }}{\text { Total surface of the stomac }}\right) \times 100
$$

\subsubsection{Determination of the mean area of the mice stomach}

The mean area of the stomach of the mouse was determined as follows:

- In a number of 10 mice that received any treatment, the stomach was removed and opened.

- On the glandular part of each stomach was placed a millimetered paper soaked in oil (to make it more translucent) and the number of tiles inscribed was counted. The half-tiles were counted as whole but with only one side between the left and the right, and between the top and the bottom.

- The area of each stomach was calculated assuming that each tile was $1 \mathrm{~mm}^{2}$ in area and the average of the ten surfaces was finally calculated; which allowed us to find an average surface area of $204.42 \mathrm{~mm}^{2}$.

\subsubsection{Measurement of mucus production}

After estimating the degree of lesion formation, the gastric mucosa of each rat was immediately scraped gently using a glass slide and the mucus obtained was weighed using a precision electronic balance. The same experimenter performed this operation each time.

\subsection{Statistical Analysis}

Statistical analysis was done by one-way analysis of variance (ANOVA) followed by the
Tukey's post-test for multiple comparisons using Graphpad Prism 05 software and $p$ values less than 0.05 were considered as significant. The results were expressed as mean \pm standard error of mean (SEM).

\section{RESULTS}

\subsection{Phytochemical Characteristics of Extract}

The result of preliminary phytochemical analysis shows that the aqueous stem bark extract of $M$. lucida possess catechic tannins, triterpenes, flavonoïds, alkaloïds, saponins and phenols. While sterols and galic tannins were absent (Table 1).

\subsection{Antioxidant Activity}

The ferric reducing antioxidant power (FRAP) of the aqueous stem bark extract of $M$. lucida was $994.53 \pm 6.11 \mathrm{mg} / \mathrm{g}$ ascorbic acid equivalent. Antioxidant capacity, measured as a function of the extract polyphenols content, was $299.89 \pm$ $1.62 \mathrm{mg} / \mathrm{g}$ ascorbic acid equivalents, while the percentage DPPH radical scavenging activity was 49.44 .

\subsection{Analgesic Properties}

\subsubsection{Acetic acid-induced writhing test}

Aqueous stem bark extract of Morinda lucida strongly reduced writhing and stretching induced by the i.p. administration of acetic acid solution. As can be seen on Table 2, extract exhibited significant protection at 100,200 and $400 \mathrm{mg} / \mathrm{kg}$ $(p<0.001)$ with maximum percentage inhibition of constrictions of $80.22 \%$ observed at $400 \mathrm{mg} / \mathrm{kg}$ while indomethacin $(50 \mathrm{mg} / \mathrm{kg})$ had only $83.76 \%$ inhibition.

\subsubsection{Formalin- induced pain test}

The results of this assay are presented in Table 3 . There was a significant $(p<0.01)$ reductions in response to nociception during the first and second phases of the pain at all extract doses. Maximum percentage inhibition of nociceptive

\begin{tabular}{|c|c|c|c|c|c|c|c|}
\hline Triterpenes & Sterols & Flavonoïds & Alkaloïds & Phenols & Saponins & $\begin{array}{l}\text { Galic } \\
\text { tannins }\end{array}$ & $\begin{array}{l}\text { Catechic } \\
\text { tanins }\end{array}$ \\
\hline+ & - & + & + & + & + & - & + \\
\hline
\end{tabular}

Table 1. Qualitative phytochemical composition of the aqueous stem barks extract of $M$. lucida 
Table 2. Antinociceptive effect of the aqueous stem bark extract of Morinda lucida on writhing induced by acetic acid in mice

\begin{tabular}{llll}
\hline Groups & Doses $\mathbf{~} \mathbf{m g} / \mathbf{k g})$ & Number of writhings within $\mathbf{3 0} \mathbf{~ m n}$ & Inhibition (\%) \\
\hline Control & $/$ & $122.16 \pm 16.74$ & $/$ \\
Indomethacin & 50 & $19.83 \pm 5.90^{* * *}$ & 83.76 \\
M. lucida & 100 & $41.00 \pm 2.62^{* * *}$ & 66.43 \\
M. lucida & 200 & $32.00 \pm 2.35^{* * *}$ & 73.80 \\
M. lucida & 400 & $24.16 \pm 1.72^{* * *}$ & 80.22 \\
\hline \multicolumn{2}{l}{ Each value represents the mean \pm ESM of 6 animals. $\quad p<0,001$ statistically significant compared to control }
\end{tabular}

Table 3. Antinociceptive effect of the aqueous stem bark extract of Morinda lucida on formalininduced pain in mice

\begin{tabular}{llllll}
\hline Groups & $\begin{array}{l}\text { Doses } \\
(\mathbf{m g} / \mathbf{k g})\end{array}$ & First phase (0-5 $\mathbf{~ m n})$ & $\begin{array}{l}\text { Inhibition } \\
(\%)\end{array}$ & $\begin{array}{l}\text { Second phase (15- } \\
\mathbf{3 0} \mathbf{~ m n})\end{array}$ & $\begin{array}{l}\text { Inhibition } \\
\text { (\%) }\end{array}$ \\
\hline Control & $/$ & $267,52 \pm 5,82$ & $/$ & $741,24 \pm 33,00$ & $/$ \\
Indomethacin & 50 & $259,09 \pm 14,77$ & 03.15 & $356,14 \pm 33,01^{* * *}$ & 51.95 \\
M. lucida & 100 & $191,33 \pm 23,55^{\star a}$ & 28.48 & $338,66 \pm 97,200^{* * *}$ & 54.31 \\
M. lucida & 200 & $130,50 \pm 11,90^{\star * * a a a}$ & 51.22 & $217,86 \pm 44,67^{* * *}$ aa & 70.61 \\
M. lucida & 400 & $124,53 \pm 13,15^{\star \star * a a a}$ & 53.45 & $178,77 \pm 31,30^{* * *}$ aaa & 75.88 \\
\hline
\end{tabular}

Each value represents the mean \pm ESM of 6 animals. $p<0,05$ statistically significant compared to control; $p<0,001$ statistically significant compared to control; ${ }^{a} p<0,001$ statistically significant compared to indomethacin; ${ }^{a a} p<0,01$ statistically significant compared to indomethacin;

${ }^{a a a} p<0,001$ statistically significant compared to indomethacin

effect was $75.88 \%$ in the second phase at $400 \mathrm{mg} / \mathrm{kg}$. Indomethacin was significantly active $(51.95 \%, p<0.001)$ only on second phase. During the two phases, the aqueous stem bark extract of Morinda lucida (200 and $400 \mathrm{mg} / \mathrm{kg}$ ) was significantly $(p<0.01)$ active than indomethacin (50 mg/kg).

\subsection{Non-ulcerogenic Properties}

Fig. 1 shows the appearance of the mice stomach five hours after the various treatments.
It appears that the distilled water as well as the different doses of extract produced any ulceration in opposition to indomethacin, which caused ulcerations with an ulcer index of 2.5 corresponding to an ulcerated surface area of $2.71 \mathrm{~mm}^{2}$. Moreover, unlike indomethacin, which inhibited mucus synthesis, the aqueous stem bark extract of Morinda lucida at doses of $200 \mathrm{mg} / \mathrm{kg}$ and $400 \mathrm{mg} / \mathrm{kg}$ induced significantly $(p<0.05)$ increase in mucus secretion compared to control and indomethacin (Table 4).
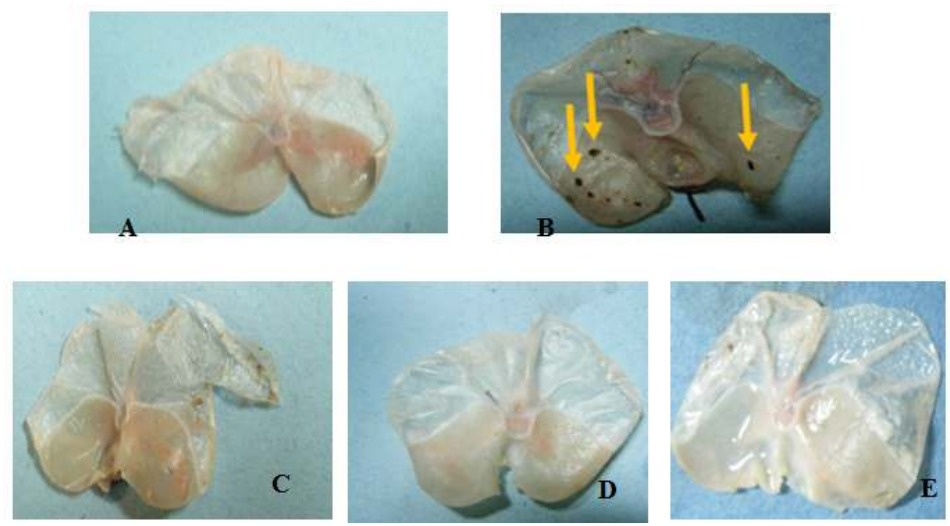

Fig. 1. Macroscopic aspect of the gastric mucosa in mice

(A) Normal control group. (B) Group treated with indomethacin (50 mg/kg) (ulcer control). (C), (D) and (E) Groups treated with aqueous extract of Morinda lucida respectively at $100 \mathrm{mg} / \mathrm{kg}, 200 \mathrm{mg} / \mathrm{kg}$ and $400 \mathrm{mg} / \mathrm{kg}$. 
Table 4. Non-ulcerogenic effect of the aqueous stem bark extract of Morinda lucida on the gastric mucosal in mice

\begin{tabular}{|c|c|c|c|c|c|}
\hline Groups & $\begin{array}{l}\text { Doses } \\
(\mathrm{mg} / \mathrm{kg})\end{array}$ & $\begin{array}{l}\text { Mucus } \\
\text { production }(\mathrm{mg})\end{array}$ & $\begin{array}{l}\text { Ulcerated } \\
\text { surface }\left(\mathrm{mm}^{2}\right)\end{array}$ & Ulcer index & $\begin{array}{l}\text { \% of Ulcerated } \\
\text { surface }\end{array}$ \\
\hline Control & i & $12.16 \pm 1.32$ & 0.00 & 0.00 & 00 \\
\hline Indomethacin & 50 & $5.00 \pm 0.68$ & $5.54 \pm 2,09$ & $2.50 \pm 0.60$ & $2.71 \pm 1.02$ \\
\hline M. lucida & 100 & $14.16 \pm 1.19^{\text {aa }}$ & 0.00 & 0.00 & 0.00 \\
\hline M. lucida & 200 & $19.50 \pm 3.05^{\text {aaa }}$ & 0.00 & 0.00 & 0.00 \\
\hline M. lucida & 400 & $22.00 \pm 0.57^{* \text { ааа }}$ & 0.00 & 0.00 & 0.00 \\
\hline
\end{tabular}

\section{DISCUSSION}

The aqueous stem bark extract of Morinda lucida (ASBEML) caused a significant $(p<0.05)$ dosedependent inhibition of the number of abdominal contractions induced by the intraperitoneal injection of acetic acid (Table 2). Pain induced by acetic acid in mice is described as a typical pattern of inflammatory pain. It is used as an instrument for evaluating the analgesic properties of drogues. Intraperitoneal injection of acetic acid causes pain, either by stimulating chemoreceptors via the activation of ASIC (AcidSensing lonic Channel) channels, or by irritating the visceral surface leading to the release of many chemical mediators involved in pain such as histamine, prostaglandins $\mathrm{E}_{2} \quad\left(\mathrm{PGE}_{2}\right)$, serotonin, bradykinin [27]. Indeed, Deraedt et al. [28] found large amounts of $\mathrm{PGE}_{2}$ and prostaglandins $\mathrm{F}_{2}\left(\mathrm{PGF}_{2}\right)$ in the peritoneal exudate of rats, the first 30 minutes after acetic acid injection. In addition, Ito et al. [29] demonstrated that $\mathrm{PGE}_{2}$ induces acute cramps in response to noxious chemical stimuli. ASBEML could thus act either by blocking the ASIC channels or by inhibiting the synthesis of prostaglandins and other mediators of pain [30]. Acetic acid also induces the synthesis of chemical mediators at the central level, such as substance P. Also, the anti-nociceptive properties of opioids, partial agonists of opioids and nonsteroidal anti-inflammatory drugs can be determined by this method. The results of this test do not make it possible to say with precision in which of these three classes lies this extract. Since acetic acid simulates both the effects of peripheral and central pain, this method is insufficient to locate the site of action of ASBEML.

It was therefore with the aim of locating the site of action of ASBEML that a second test was carried out, namely the induction of pain by formaldehyde. Formaldehyde has the advantage of separating the components of peripheral pain from central pain [31]. Injecting a solution of formaldehyde into the mouse causes a diphasic response. The first phase, called neurogenic, is triggered immediately after the injection of the formaldehyde solution. It is characterized by the release of substance $P$ and stimulation of the vanilloid receptors with transmission of the nerve message by the $C$ fibers. The second phase, called the inflammatory or peripheral phase, is due to the local inflammatory pain caused by the production of serotonin, bradykinin, histamine and prostaglandins [32]. Central analgesics such as opioids inhibit both phases of this test while peripheral analgesics (NSAIDs) act on the peripheral phase [33]. The second phase of this test is used to determine the anti-hyperalgesic effects of certain substances on models of neuropathic pain [34]. The present study shows that ASBEML significantly $(p<0.05)$ reduced the two phases of pain induced by formaldehyde injection with more pronounced action in the second phase (Table 3 ). This suggests that the analgesic effect of ASBEML may be due to inhibition of substance $P$ synthesis and / or blockade of vanilloid receptors. This analgesic effect would also be due to the inhibitory action of ASBEML on the synthesis of proinflammatory mediators (bradykinin, serotonin, histamine and prostaglandins) or inhibition of the nociceptive effect of neurotransmitters (glutamate) which act as a facilitator descending from pain [35]. The presence of flavonoids and tannins in ASBEML [36] may be at the origin of the observed analgesic effect. Flavonoids and tannins have been shown to have potent analgesic effects [37]. Indeed, flavonoids are inhibitors of the synthesis of prostaglandins, powerful mediators of pain [38]. The pronounced action of ASBEML on the second phase of formaldehyde-induced pain and on pain induced by acetic acid suggests that the ASBEML acts via prostaglandins like 
NSAIDs. NSAIDs (indomethacin) cause peptic ulcers in patients. It was therefore necessary to carry out an ulcerogenic test to verify whether ASBEML has this side effect.

There are two types of cyclooxygenase (COX) in the body: cyclooxygenase 1 (COX1) and cyclooxygenase 2 (COX2). COX 2, known as inducible, is responsible for the synthesis of prostaglandins during inflammatory reactions. COX 1 is a constitutional enzyme that governs the synthesis of prostaglandins involved in gastric cytoprotection. NSAIDs such as indomethacin act by inhibiting COX 1 and 2. This results in an inhibition of the synthesis of prostaglandins, a potent mediator of pain. However, prostaglandins play an important cytoprotective role in the stomach. They stimulate the secretion of mucus and $\mathrm{HCO}_{-}$ bicarbonate ions which protect the gastric mucosa [7]. The inhibition of prostaglandin synthesis by NSAIDs is directly correlated with the onset of gastric ulcers, as shown by the ulcerogenic test (Table 4). ASBEML at all doses did not cause gastric ulcer. On the contrary, this extract stimulated mucus secretion (Table 4). This suggests that ASBEML acts by selectively inhibiting COX 2. The increase in mucus secretion may be due to the stimulation of prostaglandin synthesis via COX1 or by direct stimulation of production of mucus by triterpenes [39]. The presence of triterpenes in ASBEML, as revealed by Addy et al. [35], was confirmed by phytochemical tests (Table 1). This extract of Morinda lucida could therefore also have antiulcerogenic effects.

In vitro, Folin test revealed that ASBEML had a total polyphenol content of $299.89 \pm 1.62 \mathrm{mg}$ Ascorbic acid / g of dry extract. This result suggests that this extract is rich in polyphenols. Using the DPPH method, this extract exhibited an antiradical activity of $49.44 \%$. ASBEML shows a slightly higher antiradical activity than the aqueous stem bark extract of Alstonia boonei $(41.58 \%)$ [40]. This antioxidant activity is linked to the richness of the polyphenol extract. The polyphenolic compounds have an antioxidant activity linked to the redox properties which enable them to act as reducing agents, metal chelators and as free radical scavengers [41]. In addition, Sokol-Letowska's study shows that phenolic compounds (flavonoids, tannins) possess significant antioxidant activity [42]. This is due to the presence of many hydroxide groups that can react with free radicals. This antioxidant activity is confirmed by the FRAP test which reveals an antioxidant potential of ASBEML of $994.53 \pm 6.11 \mathrm{mg}$ Ascorbic acid / g of dry extract, ie $99453 \mathrm{mg}$ of ascorbic acid / $100 \mathrm{~g}$ of dry extract. Most effective medicinal plants are rich in polyphenols and possess high antioxidant potential [40]. In addition, ASBEML leads to an increase in the concentration of super oxide dismutase (SOD) and catalase, and a decrease in malondialdehyde (MDA) in diabetic rats [14].

\section{CONCLUSION}

The aqueous stem bark extract of Morinda lucida possesses analgesic and antioxidant properties, and has anti-ulcerogenic properties. This would justify the use of this plant in traditional medicine.

\section{COMPETING INTERESTS}

Authors have declared that no competing interests exist.

\section{REFERENCES}

1. IASP (International Association for the Study of Pain) Pain terms: A list with definitions and notes on usage. Recommended by the IASP Subcommittee on Taxonomy. Pain. 1979;6:249.

2. Michael $T$, Smith $R$, Edwardsa RC, Robinson RH, Dworkinc. Suicidal ideation, plans, and attempts in chronic pain patients: Factors associated with increased risk. Pain. 2004;111(1-2):201-208.

3. Stucky CL, Gold MS, Zhang X. Mechanism of pain. Proceedings of the National Academy of Sciences USA. 2001;98(21): 11845-11846.

4. Thomas E, Peat G, Harris L, Wilkie R, Croft PR. The prevalence of pain and pain interference in a general population of older adults: Cross sectional findings from the North Staffordshire Osteoartritis project (NorStOP). Pain. 2004;110:361-368.

5. Jain N, Kulkarni S, Singh A. Modulation of NSAID-induced antinociceptive and inflammatory effects by $\mathrm{a}_{2}$ adrenoceptor agonists with gastroprotective effects. Life Sciences. 2002;70:2857-2869.

6. Kabamba A, Shamashanga L, Mwaba J, Kasongo C, Longanga A, Lukumwena $Z$. Prévalence de l'utilisation des antiinflammatoire non stéroïdiens chez les femmes enceintes à Lubumbashi (République Démocratique du Congo). Pan African Medical Journal. 2014;18: 132-137. 
7. Keita A. Etude de trois plantes utilisées dans le traitement traditionnel de l'ulcère gastro-duodénal dans le District de Bamako: Borassus æthiopum Mart (Palmeae), Sclerocarya birrea (A. Rich.). Hochst. (Anacardiaceae) et Ximenia americana L. (Olacaceae). Thèse de doctorat en pharmacie (Diplôme d'Etat), Université de Bamako, Mali; 2005.

8. Farnsworth N. In: Wilson F.O., Peter F.M. (Eds.). Biodiversity. National Academy Press, Washington. USA. 1999;83:97.

9. Capasso A. Medicinal plants and central nervous system: An overview. In: Recent developments in medicinal plant research. Ed. Research Signpost. Kerala. 2007;1-17.

10. Karou D, Tchadjobo T, Denise IP, Simpore J. Sub-Saharan Rubiaceae: A review of their traditional uses, phytochemistry and biological activities. Pakistan Journal of Biological Sciences. 2011;14:149-169.

11. Miège J. Couleurs, teintures et plantes tinctoriales en Afrique occidentale. Bulletin du Centre Genevois d'Anthropologie. 1992;3:115-131.

12. Adesida G, Adesogan EO. A novel dihydroanthraquinone pigment from Morinda lucida Benth. Journal of the Chemical Society. 1972;1:405-406.

13. Nweze N. In vitro anti-trypanosomal activity of Morinda lucida leaves. African Journal of Biotechnology. 2011;11(7): 1812-1817.

14. Domekouo UL, Longo F, Tarkang PA, Tchinda AT, Tsabang N, Donfagsiteli NT, Tamze V, Kamtchouing P, Agbor GA. Evaluation of the antidiabetic and antioxidant properties of Morinda lucida stem bark extract in streptozotocin intoxicated rats. Pak J Pharm Sci. 2016; 29(3):903-11.

15. Agbor G, Tarkam A, Fogha J, Biyiti L, Tamze V, Messi $\mathrm{H}$, Tsabang $\mathrm{N}$, Longo $\mathrm{F}$, Tchinda A, Dongmo B, Donfagsiteli N, Nbing J N, Joseph K, Ngide R, Simo D. Acute and sub-acute toxicity of aqueous extract of Morinda lucida stem bark. Journal of Pharmacology and Toxicology. 2012;7(3):158-165.

16. Lawal HO, Etatuvie SO, Fawehinmi AB. Ethnomedicinal and pharmacological properties of Morinda lucida. Journal of Natural Products. 2012;5:93-99

17. Ogunlana OE, Olubanke O, Farombi OE. Morinda lucida: Antioxidant and reducing activities of crude methanolic stem bark extract. Advances in Natural and Applied Sciences. 2008;2(2):49-54.

18. Adeyemi TOA, Ogboru RO, Idowu OD, Owoeye EA, Isese MO. Phytochemical screening and health potentials of Morinda lucida Benth. International Journal of Innovation and Scientific Research. 2014; 11(2):515-519

19. Bruneton J. Phytochemistry pharmacognosy of medicinal plants: Technics. $2^{\text {nd }}$ Edition Lavoisier; 1993.

20. Singleton VL, Orthofer R, LamuelaRavent'os RM. Analysis of total phenols and other oxidation substrates and antioxidants by means of folin-ciocalteu reagent. Methods in Enzymology. 1998; 299:152-178.

21. Benzie IFF, Strain JJ. The ferric reducing ability of plasma (FRAP) as a measure of "antioxidant power": The FRAP assay. Analytical Biochemistry. 1996;239(1):7076.

22. Hatano T, Kagawa H, Yasuhara T, Okuda T. Two new flavonoids and other constituents in licorice root: Their relative astringency and radical scavenging effects. Chemical and Pharmaceutical Bulletin. 1988;36(6):2090-2097.

23. Koster R, Anderson M, De Beer E. Acetic acid analgesic screen. Federation Proceedings. 1959;18:418-420.

24. Gaertner M, Müller L, Rooss J. Analgesic effects of triterpenes from Sebastiana schottiana roots. Phytomedecine. 1999;6: 41-44.

25. Grewal T, Ojjha S. Antioxidant, antiulcer and analgesic properties of methanolic leaf extract (Chloroform insoluble fraction) of Lantana camara. International Journal of Pharmacological and Toxicological Science. 2014;4(2):1-12.

26. Martin M, Motilva V, Alarcon de la Lastra C. Quercetin and naringenin: Effects on ulcer formation and gastric secretion in rats. Phytotherapy Research. 1993;7: 150-153.

27. Bomba $\mathrm{T}$, Mbiantcha $\mathrm{M}$, Ngeulefack $\mathrm{T}$, Watcho $P$, Oumar M, Ngoupaye T, Kamanyi A. Anti-nociceptive activities of aqueous extract of the stem bark of Drypetes gossweileri (Euphorbiaceae) in mice and rats. International Journal of Biological and Pharmaceutical Research. 2013;4(8):559-563.

28. Derardt $R$, Jougney $S$, Delevalcee $F$, Falhout M. Release of prostaglandins $E$ and $F$ in an algogenic re action and its 
inhibition. European Journal of Pharmacology. 1980;51:17-24.

29. Ito S, Okuda-Ashitaka E, Minami T. Central and peripheral roles of prostaglandins in pain and their interactions with novel neuropeptides nociception and nocistation. Neuroscience Research. 2001;41:299332.

30. Ukwuani NA, Hassan FF. Analgesic properties of Tamarindus indica L. stem bark fractions in albino rats. Sky Journal of Biochemical Research. 2014;3(2):24-27

31. Godínez-Chaparro B, López-Santillán FJ, Argüelles CF, Villalón CM, Granados-Soto $\mathrm{V}$. Role of 5 -HT receptors in the reduction of formalin-induced nociception and secondary allodynia / hyperalgesia produced by antimigraine drugs in rats. Life Science. 2013;92:1046-1054.

32. Fischer MJ, Btesh J, McNaughton PA. Disrupting sensitization of transient receptor potential vanilloid subtype 1 inhibits inflammatory hyperalgesia. Journal Neurosciences. 2013;33:7407-7414.

33. Gorzalczany S, Marrassini C, Mino J. Antinociceptive activity of ethanolic extract and isolated compounds of Urtica circularis. Journal of Ethnopharmacology. 2011;134:733-738.

34. Iliya HA, Boakye-Gyasi E, Adongo WD, Ampadu FA, Woode E. Antinociceptive activity of various solvent extracts of Maerua angolensis DC stem bark in rodents. Phytopharmacology. 2014;13:1-8.

35. Azi lliya $\mathrm{H}$, Woode $\mathrm{E}$. Evaluation of analgesic property of petroleum ether/ethyl acetate stem bark extract and fractions of Maerua angolensis in Murine models of pain. Journal of Applied Pharmaceutical Science. 2015;5(02):91-102.

36. Addy B, Owodo H, Gyapong R, Umeji C, Mintah D. Phytochemical screening and antimicrobial study on the leaves of Morinda lucida (Rubiaceae). Journal of Natural Sciences Research. 2013;14(3): $2224-3186$.

37. Ching FP, Faloduna A. Dimethoxyflavone, a flavonoid from Stereospermum kunthianum Stem bark with analgesic and anti-inflammatory activities. West African Journal of Pharmacological Drug Research. 2011;27:16 -20.

38. Kumar N, Goldminz AM, Kim N, Gottlieb AB. Phosphodiesterase 4-targeted treatments for autoimmune diseases. BMC Med. 2013;11:96-10.

39. Astudillo L, Roriguez J, SchmedaHirschmann G. Gastroprotective activity of oleanolic acid derivatives on experimentally induced gastris lesions in rats and mices. Journal of pharmacy and Pharmacology. 2002;54(4):583-588.

40. Akinmoladun AC, Ibukun EO, Afor E, et al. Chemical constituents and antioxidant activity of Alstonia boonei. African Journal of Biotechnology. 2007;6(10):1197-1201.

41. Rice-Evans CA, Miller NJ, Paganga G. Structure antioxidant activity relationships of flavonoids and phenolic acids. Free Radical Biology and Medicine. 1996;20(7): 933- 956.

42. Sokol-Letowska A, Oszmiansk J, wojdylo A. Antioxidant activity of the phenolic compounds of Hawthorn, pine and skullcap. Food Chemistry. 2007;103:853859 .

(c) 2017 Christophe et al.; This is an Open Access article distributed under the terms of the Creative Commons Attribution License (http://creativecommons.org/licenses/by/4.0), which permits unrestricted use, distribution, and reproduction in any medium, provided the original work is properly cited.

Peer-review history:

The peer review history for this paper can be accessed here: http://sciencedomain.org/review-history/19094 